\title{
PENGARUH MODEL PEMBELAJARAN MODELLING THE WAY TERHADAP PELAKSANAAN IBADAH SEHARI-HARI
}

\author{
Ardi Rakasiwi ${ }^{1)}$ \\ 1) UIN Sunan Gunung Djati Bandung, Jalan A.H. Nasution No. 105, Cipadung, Cibiru, \\ Kota Bandung, Jawa Barat 40614 \\ Email: 1142020020@student.uinsgd.ac.id
}

\begin{abstract}
This research was conducted because there are still students who are good in terms of cognitive, but the implementation of daily worship is still not good. The purpose of this study was to determine the reality of the implementation of daily worship of students by using the Modeling The Way learning method. This research is based on the assumption that the selection of appropriate learning methods in the PAI subject matter of Fiqh will be closely related to the implementation of students' daily worship and methods Modeling learning The Way is one of the right learning methods for learning Fiqh. The method used in this study is descriptive correlational method. The sample in this study amounted to 30 students of SMP Negeri 17 Bandung. While the data collection techniques using questionnaires, observation, interviews and literature studies. Then to analyze the data using two approaches namely descriptive analysis and correlation analysis. After analyzing the data obtained, it can be concluded that (1) students' response to the application of the Modeling Learning method is very high, it is based on a score of 4.397 at intervals from 4.20 to 5.00; (2) The implementation of the daily worship of students is included in the high qualifications, it is based on a score of 3.81 in the interval 3.40 - 4.19; and (3) The influence between the two is (a) The correlation coefficient number is 0.67 , the number is included in the high qualification because it is in the interval 0.60 - 0.69; (b) The hypothesis is accepted, namely the existence of a significant relationship between variable $X$ and variable $Y$ because $t$ count $>t$ table or 4.78> 2.763; and (c) The degree of influence of $X$ variable on $Y$ variable is $26 \%$, so there are still $74 \%$ of other factors that influence the implementation of daily worship of students of SMP Negeri 17 Bandung.
\end{abstract}

Keywords:

Modelling The Way, Implementation of Worship, PAI

\begin{abstract}
Abstrak : Penelitian ini dilakukan karena masih ada siswa yang baik dalam hal kognitif namun pada pelaksanaan ibadah sehari-harinya masih kurang baik. Tujuan dari penelitian ini adalah untuk mengetahui realitas pelaksanaan ibadah sehari-hari siswa dengan menggunakan metode pembelajaran Modelling The Way.Penelitian ini didasarkan pada asumsi bahwa pemilihan metode pembelajaran yang tepat pada materi PAI subbab Fiqih akan sangat berkaitan dengan pelaksanaan ibadah sehari-hari siswa dan metode pembelajaran Modelling The Way lah salah satu metode pembelajaran yang tepat untuk pembelajaran Fiqih. Metode yang digunakan dalam penelitian ini adalah metode deskriptif korelasional. Sampel dalam penelitian ini berjumlah 30 orang siswa SMP Negeri 17 Bandung. Sedangkan teknik pengumpulan datanya dengan menggunakan angket, observasi, wawancara dan studi kepustakaan. Kemudian untuk analisis datanya menggunakan dua pendekatan yaitu analisis deskriptif dan analisis korelasi.Setelah dilakukan analisis terhadap data yang diperoleh, maka dapat disimpulkan bahwa (1) Tanggapan siswa terhadap penerapan metode pembelajaran Modelling The Way termasuk pada kualifikasi sangat tinggi, hal tersebut berdasarkan skor 4,397 berada pada interval 4,20 - 5,00; (2) Pelaksanaan ibadah sehari-hari siswa termasuk pada kualifikasi tinggi, hal tersebut berdasarkan skor 3,81 berada pada interval 3,40 - 4,19; dan (3) Pengaruh antara keduanya adalah (a) Angka koefisien korelasi sebesar 0,67, angka tersebut termasuk pada kualifikasi tinggi karena berada pada interval $0,60-0,69$; (b) Hipotesisnya diterima yaitu adanya
\end{abstract}


hubungan yang signifikan antara variabel $\mathrm{X}$ dengan variabel $\mathrm{Y}$ karena $\mathrm{t}$ hitung $>\mathrm{t}$ tabel atau 4,78 $>2,763$ ; dan (c) Derajat pengaruh variabel X terhadap variabel Y sebesar 26\%, sehingga masih terdapat $74 \%$ faktor lain yang mempengaruhi pelaksanaan ibadah sehari-hari siswa SMP Negeri 17 Bandung.

Kata kunci:

Modelling The Way, Pelaksanaan Ibadah, PAI

\section{PENDAHULUAN}

Prestasi belajar merupakan salah satu tolok ukur dari keberhasilan dalam proses pembelajaran. Ini berarti prestasi belajar yang diperoleh siswa merupakan cerminan dari penguasaan materi yang telah diberikan oleh gurunya. Pada pelaksanaannya, prestasi belajar terbagi menjadi 3 bagian, yakni prestasi belajar kognitif, afektif dan psikomotor. Prestasi belajar kognitif mencakup tentang penguasaan siswa terhadap suatu materi, prestasi belajar afektif mencakup tata krama atau sikap siswa dan prestasi belajar psikomotor mencakup praktek atau pengamalan siswa terhadap materi yang telah ia dapat di sekolah.

Pada Kurikulum Nasional 2013 yang digunakan oleh SMP Negeri 17 Bandung, prestasi belajar psikomotor merupakan salah satu hal yang sangat diperhatikan. Kemudian pada pembelajaran Pendidikan Agama Islam pada umumnya hasil yang diharapkan dari pembelajarannya siswa tidak hanya baik dalam hasil belajar dalam ranah kognitif, namun juga harus baik dalam akhlaq siswa sehari-hari serta dapat melaksanakan atau mengamalkan ibadah dalam kehidupan sehari-harinya.

Hasil belajar akan berbanding lurus dengan praktek atau pengamalan ibadah siswa sehari-hari. Namun faktanya di lapangan, masih ada siswa yang baik dalam hal kognitif namun pada pelaksanaan ibadah sehari-harinya masih kurang baik. Ada pula yang sudah melaksanakan namun masih saja disertai dengan tidak serius dalam pelaksanaannya. Ketidakseriusan ini ditandai dengan bercandanya siswa ketika beribadah. Beberapa contoh masalah berkaitan dengan pelaksanaan ibadah sehari-hari siswa di SMP Negeri 17 Bandung dalam pelaksanaan shalat Dzuhur berjamaah masih banyak siswa yang belum sadar akan kewajibannya shalat berjamaah, kemudian dalam pembiasaan baca tulis Al Quran masih banyak siswa yang tidak mengikuti pembiasaan tersebut begitu pula dengan pembiasaan shalat Dhuha bersama setiap Jumat pagi sebelum pembelajaran dimulai, masih banyak siswa meyepelekan pembiasaan ini sehingga mereka sengaja datang terlambat agar tidak mengikuti pembiasaan Dhuha tersebut.

Pada penelitian skripsi yang telah dilakukan sebelumnya oleh Muhamad Nasrudin pada tahun 2017 di Madrasah Diniyah Cikajang Garut dijelaskan bahwa keterampilan atau psikomotor siswa dipengaruhi oleh metode yang digunakan guru dalam sebuah pembelajaran. Ini berarti dalam pemilihan metode pembelajaran harus tepat dan cocok dengan siswa agar hasil yang didapatkan sesuai dengan apa yang diharapkan. 
Metode menjadi suatu jalan seorang guru mentransfer ilmunya, sedangkan murid memahami ilmu yang disampaikan melalui metode yang guru lakukan. Jika metode yang selalu digunakan metode ceramah, maka interaksi antara guru dan murid pun akan kurang, sehingga murid cenderung tidak memperhatikan apa yang materi yang disampaikan, dan minat siswa dalam belajarpun akan menurun.

Kecenderungan siswa untuk memperhatikan atau tidak memperhatikan materi yang disampaikan oleh gurunya itu disebut sebagai tanggapan. Tanggapan dipandang sebagai kekuatan psikologis yang dapat menolong atau menimbulkan keseimbangan. Kesan tersebut menjadi isi kesadaran yang dapat dikembangkan dalam hubungannya dengan konteks pengalaman waktu sekarang serta antisipasi keadaan untuk masa yang akan datang. Tanggapan siswa terhadap suatu pembelajaran dapat berupa tanggapan positif yaitu rasa menerima, menyukai, dan perhatian terhadap guru atau pelajaran atau bahkan tanggapan negatif yaitu rasa tidak menyukai, menolak atau menghindar, acuh tak acuh terhadap guru atau pelajaran. Hal ini akan terlihat pada sikap siswa pada mata pelajaran dan guru.

Dalam pembelajaran Pendidikan Agama Islam, banyak sekali hal yang dipelajari di kelas yang juga dapat dipraktekkan di kehidupan sehari-hari para siswa, salah satunya adalah pembelajaran Fiqih. Namun, praktek dari sebuah materi Fiqih itu pun bergantung terhadap pemahaman para siswa itu sendiri, jika ia paham ia praktekan, jika tidak mungkin saja dipraktekkan tapi bisa jadi salah atau kurang tepat. Hal ini disebutkan oleh Mumuh Mulyana dalam penelitian skripsinya pada tahun 2013 di SMA Plus Babussalam Bandung tentang hubungan pemahaman siswa terhadap materi Fiqih dengan pengalaman ibadah sehari-hari siswa.

Dalam pembelajaran Pendidikan Agama Islam pula sering dijumpai guru hanya menggunakan metode yang monoton, menyampaikan materi melalui ceramah, pemberian tugas dan mengerjakan soal yang ada dibuku paket, sehingga pembelajaran kurang menarik, hal ini menyebabkan proses pembelajaran menjadi membosankan. Proses pembelajaran yang membuat siswa merasa bosan berakibat pada proses pembelajaran tersebut kurang mendorong siswa untuk berpartisipasi aktif dalam kegiatan pembelajaran dan siswa kurang mengerti materi yang disampaikan gurunya serta rendahnya praktek atau pengamalan dari materi tersebut.

Berdasarkan studi pendahuluan yang dilakukan, metode pembelajaran Modelling The Way yang dilaksanakan di kelas VII SMP Negeri 17 Bandung telah sesuai dengan langkah-langkah pembelajaran metode pembelajaran Modelling The Way, yakni :

1. Setelah pembelajaran satu topik tertentu, identifikasi beberapa masalah dan siswa di tuntut untuk mengunakan keterampilan yang dibahas.

2. Membagi kelas ke dalam beberapa kelompok kecil menurut jumlah siswa yang diperlukan untuk mendemonstrasi satu skenario (minimal 2 atau 3 orang)

3. Memberi waktu 10-15 menit untuk menciptakan skenario. 
4. Memberi waktu 5-7 menit untuk pelatihan.

5. Secara bergiliran tiap kelompok mendemonstrasikan skenario masing-masing.

6. Memberi kesempatan untuk memberikan feedback pada setiap demonstrasi yang dilakukan.

Berdasarkan teori Modelling The Way, seharusnya jika pelaksanaan sesuai dengan teori yang ada maka itu akan berpengaruh terhadap pelaksanaan ibadah seharihari siswa di SMP Negeri 17 Bandung. Namun pada realitanya masih banyak siswa yang belum sadar akan kewajibannya shalat berjamaah, kemudian dalam pembiasaan baca tulis Al Quran masih banyak siswa yang tidak mengikuti pembiasaan tersebut begitu pula dengan pembiasaan shalat Dhuha bersama setiap Jumat pagi sebelum pembelajaran dimulai, masih banyak siswa meyepelekan pembiasaan ini.

Berdasarkan latar belakang masalah tersebut, ada beberapa rumusan masalah yang muncul, yakni :

1. Apa tanggapan siswa terhadap penerapan metode pembelajaran Modelling The Way pada mata pelajaran PAI sub bab Fiqih di SMP Negeri 17 Bandung?

2. Bagaimana pelaksanaan ibadah sehari-hari siswa di SMP tersebut?

3. Sejauhmana pengaruh penerapan metode pembelajaran Modelling The way pada mata pelajaran PAI sub bab Fiqih terhadap pelaksanaan ibadah sehari-hari siswa di SMP tersebut?

Maka turunan dari rumusan masalah itu memunculkan tujuan penelitian yaitu :

1. Untuk mengetahui tanggapan siswa terhadap penerapan metode pembelajaran Modelling The Way pada mata pelajaran PAI sub bab Fiqih di SMP Negeri 17 Bandung.

2. Untuk mengetahui pelaksanaan ibadah sehari-hari siswa di SMP tersebut.

3. Untuk mengetahui pengaruh penerapan metode pembelajaran Modelling The Way pada mata pelajaran PAI sub bab Fiqih terhadap pelaksanaan ibadah seharihari siswa di SMP tersebut.

Metode adalah cara dan pembelajaran adalah proses yang dilakukan guru dan siswa untuk belajar mengajar yang di dalamnya terdapat interaksi antara keduanya. Jadi, metode pembelajaran adalah cara yang digunakan guru dalam proses belajar mengajar bersama siswa agar tercipta interaksi yang baik antara keduanya. Hal ini selaras dengan apa yang dikatakan oleh Sudjana dalam bukunya, metode mengajar adalah cara yang dipergunakan guru dalam mengadakan hubungan dengan siswa pada saat berlangsungnya pengajaran (Sudjana, 2001). Oleh karenanya metode pembelajaran digunakan sebagai alat dalam proses belajar mengajar. Dengan penggunaan sebuah metode pembelajaran diharapkan terciptanya interaksi yang efektif antara guru dan siswa serta siswa lebih aktif dibandingkan gurunya.

Sebelum melaksanakan sebuah pembelajaran tentunya seorang guru harus mempersiapkan perencanaan yang matang, perencanaan yang matang ini salah satunya adalah mempersiapkan metode pembelajaran yang akan digunakan dalam sebuah 
pembelajaran. Penggunaan metode pembelajaran ini sangat berpengaruh terhadap hasil belajar siswa, oleh karena itu dalam pemilihan sebuah metode pembelajaran haruslah memilih metode yang tepat. Metode pembelajaran tidak berdiri sendiri, maka harus pula mengetahui hal-hal yang mendukung dari sebuah metode. Terkadang metode yang satu tepat digunakan pada materi A, namun belum tentu tepat digunakan pada materi B. Dari penjelasan tersebut membuktikan bahwa pemilihan metode pembelajaran yang tepat adalah salah satu cara untuk menjadikan hubungan antara guru dan siswa lebih efektif dan dapat menghasilkan suatu ouput pembelajaran yang baik bagi siswa.

Ketika pemilihan metode pembelajaran hanya berpusat pada seorang guru saja, tanggapan siswa pun tidak akan antusias. Tanggapan merupakan salah satu fungsi kejiwaan yang dapat diperoleh individu setelah proses pengamatan selesai(Baharuddin, 2007). Sementara itu menurut ahli yang lain tanggapan ialah gambaran pengamatan yang tinggal di kesadaran kita sesudah mengamati (Sujanto, 2012).

Memperkuat pendapat sebelumnya, tanggapan didefinisikan sebagai hasil bayangan yang menjadi kesan yang dihasilkan dari pengamatan (Soemanto, 2012). Tanggapan dipandang sebagai kekuatan psikologis yang dapat menolong atau menimbulkan keseimbangan. Kesan tersebut menjadi isi kesadaran yang dapat dikembangkan dalam hubungannya dengan konteks pengalaman waktu sekarang serta antisipasi keadaan untuk masa yang akan datang. Ada tiga macam tanggapan, yaitu :

1. Tanggapan masa lampau (tanggapan ingatan).

2. Tanggapan masa sekarang (tanggapan imajinatif).

3. Tanggapan masa mendatang (tanggapan antisipatif).

Tanggapan yang dipakai dalam penelitian ini memiliki indikator sebagai berikut:

1. Tanggapan positif yaitu rasa menerima, menyukai, dan perhatian terhadap guru atau pelajaran.

2. Tanggapan negatif yaitu rasa tidak menyukai, menolak atau menghindar, acuh tak acuh terhadap guru atau pelajaran. Hal ini akan terlihat pada sikap siswa pada mata pelajaran dan guru.

Metode Modelling The Way adalah metode yang dapat memberikan kesempatan kepada siswa untuk mempraktekkan keterampilan spesifik yang dipelajari di kelas melalui demonstrasi. Namun keistimewaannya dibandingkan dengan metode demonstrasi adalah metode Modelling The Way membuat siswa lebih aktif dalam belajar, siswa menjadi lebih berani untuk mempraktekkan sesuatu dan tidak takut, siswa aktif memberikan tanggapan, menambahkan kesadaran akan tanggungjawab terhadap tugas yang diberikan dan siswa mengalami langsung keterampilan yang dipraktekkan.

Siswa diberi waktu untuk menciptakan skenario sendiri dan menentukan bagaimana mereka mengilustrasikan keterampilan dan teknik yang baru saja dijelaskan. Metode ini sangat baik digunakan untuk mengajarkan pelajaran yang menuntut keterampilan tertentu (Zaini, 2008).

Langkah-langkah penerapan metode Modelling The Way adalah : 
1. Setelah pembelajaran satu topik tertentu, identifikasi beberapa masalah dan siswa di tuntut untuk mengunakan keterampilan yang dibahas.

2. Membagi kelas ke dalam beberapa kelompok kecil menurut jumlah siswa yang diperlukan untuk mendemonstrasi satu skenario (minimal 2 atau 3 orang)

3. Memberi waktu 10-15 menit untuk menciptakan skenario.

4. Memberi waktu 5-7 menit untuk pelatihan.

5. Secara bergiliran tiap kelompok mendemonstrasikan skenario masing-masing.

6. Memberi kesempatan untuk memberikan feedback pada setiap demonstrasi yang dilakukan.

Siswa diberi waktu untuk menciptakan skenario sendiri dan menentukan bagaimana mereka mengilustrasikan keterampilan dan teknik yang baru saja dijelaskan. Metode ini sangat baik digunakan untuk mengajarkan pelajaran yang menuntut keterampilan tertentu (Zaini, 2008). Hal ini menunjukkan bahwa siswa akan terlibat aktif dalam pembelajaran dan pembelajaran bersifat latihan langsung.

Dengan demikian jelaslah bahwa pemilihan metode pembelajaran yang tepat pada materi PAI sub bab Fiqih akan sangat berkaitan dengan pelaksanaan ibadah seharihari siswa. Pada penelitian ini, penulis menentukan Variabel X yaitu penerapan metode pembelajaran Modelling The Way pada mata pelajaran PAI sub bab Fiqih dan Variabel Y yaitu pelaksanaan ibadah sehari-hari siswa.

Hipotesis penelitian ini adalah : "Penerapan metode pembelajaran Modelling The Way pada mata pelajaran PAI sub bab Fiqih berpengaruh terhadap pelaksanaan ibadah sehari-hari siswa di SMP Negeri 17 Bandung”.

\section{METODOLOGI PENELITIAN}

Secara umum penelitian ini akan dilaksanakan dengan menggunakan penelitian deskriptif korelasional. Deskriptif merupakan penelitian yang berusaha mendeskripsikan suatu gejala, peristiwa, kejadian yang terjadi pada saat sekarang. Dengan kata lain penelitian deskriptif mengambil masalah atau memusatkan perhatian kepada masalah-masalah aktual sebagaimana adanya pada saat penelitian dilaksanakan. Mengingat sifatnya yang demikian, maka penelitian deskriptif dalam pendidikan lebih berfungsi untuk memecah masalah praktis pendidikan Studi korelasi merupakan bagian dari metode deskriptif yang mempelajari hubungan dua variabel atau lebih yakni sejauh mana variasi dalam satu variabel berhubugan dengan variasi dalam variabel lain. Derajat hubungan variabel-variabel dinyatakan dalam satu indeks yang dinamakan koefisien korelasi.

Menurut Sudjana dan Ibrahim korelasi dapat menghasilkan dan menguji suatu hipotesis mengenai hubungan antar variabel atau untuk menyatakan besar kecilnya hubungan antara kedua variabel. Dari keterangan mengenai deskriptif dan korelasi, sangat sesuai dengan judul yang diteliti yaitu memecahkan masalah praktis yang ada 
dalam pendidikan yang berhubungan antara satu variabel (Variabel X) dengan variabel yang lain (Variabel Y).

Dalam penelitian ini yang dijadikan populasi adalah seluruh siswa Kelas VII SMP Negeri 17 Bandung, berdasarkan data terbaru bulan Desember yang penulis peroleh dari pihak sekolah berjumlah 349 orang kemudian kelas yang diterapkan metode Modelling The Way sebanyak 9 kelas dengan total jumlah siswa 301 orang. Kemudian sempel yang penulis gunakan adalah $10 \%$ dari keseluruhan populasi yakni 30 orang.

Penelitian ini dilakukan di Kelas VII SMP Negeri 17 Bandung yang berlokasi di Jalan Pacuan Kuda Kecamatan Arcamanik Kota Bandung. Alasan pemilihan lokasi ini karena di lokasi ini terdapat masalah yang menarik untuk diamati, diteliti dan dikembangkan yakni adanya beberapa siswa yang masih belum baik dalam pelaksanaan ibadah sehari-harinya.

Penelitian dilaksanakan pada semester II tahun pelajaran 2017/2018 dari tanggal 21-26 Mei 2018. Sebelum penelitian dimulai, peneliti mengawali dengan observasi untuk menemukan permasalahan yang dihadapi dalam proses pembelajaran. Dalam penelitian ini, teknik pengumpulan data yang akan digunakan yakni angket, observasi, wawancara dan studi pustaka.

\section{HASIL KAJIAN DAN PEMBAHASAN}

Data yang digunakan untuk mengetahui tanggapan siswa terhadap penerapan metode pembelajaran Modelling The Way diperoleh dari hasil penyebaran angket kepada siswa kelas VII SMPN 17 Bandung yang berjumlah 30 siswa. Adapun jumlah pertanyaan yang diajukan yaitu sebanyak 10 .

Angket yang digunakan dalam penelitian ini adalah angket yang dibuat dalam bentuk checklist. Adapun cara mengidentifikasinya adalah berdasarkan kunci jawaban masing-masing berupa alternatif jawaban sangat baik (SB), baik (B), cukup (C), tidak baik (TB), dan sangat tidak baik (STB). Pengajuan item angket bersifat positif. Nilai angket tersebut akan ditransformasikan ke dalam bentuk simbol angka kuantitatif, untuk angket yang berorientasi positif, maka sistem penskorannya adalah sangat baik (SB) memiliki skor $=5$, baik $(B)$ memiliki skor $=4$, $\operatorname{cukup~}(\mathrm{C})$ memiliki skor $=3$, tidak baik (TB) memiliki skor $=2$, dan sangat tidak baik $(\mathrm{STB})$ memiliki skor $=1$. Maka dengan mengacu pada teknik perhitungan ini, akan diperoleh skor ideal tertinggi yaitu 10 x $5=$ 50 .

Adapun interpretasi hasil perhitungan menggunakan kriteria sebagai berikut :

$$
\begin{aligned}
& 4,20-5,00=\text { Sangat baik } \\
& 3,40-4,19=\text { Baik } \\
& 2,60-3,39=\text { Cukup } \\
& 1,80-2,59=\text { Tidak baik } \\
& 1,00-1,79=\text { Sangat tidak baik }
\end{aligned}
$$

(Arikunto, 2006) 
Dengan mempertimbangkan skala penilaian diatas, maka hasil dari komponenkomponen tanggapan siswa terhadap penerapan metode pembelajaran Modelling The Way dapat dilihat dalam uraian berikut :

Item nomer 1 menyatakan "Sebelum pembelajaran dimulai, guru telah menyiapkan pembelajaran dengan metode Modelling The Way. Bagaimana tanggapan Anda ?". Dari pertanyaan tersebut, diperoleh jawaban SB $=11$ orang, B = 16 orang, C $=3$ orang dan tidak ada yang memilih TB dan STB. Rata-rata yang diperoleh dari jawaban angket adalah $(11 \times 5)+(16 \times 4)+(3 \times 3)=55+64+9=128 / 30=4,27$. Nilai rata-rata tersebut berinterpretasi sangat tinggi karena berada pada rentang interval 4,20 $-5,00$.

Item nomer 2 menyatakan "Guru menyampaikan pembelajaran dengan metode Modelling The Way di depan kelas. Bagaimana tanggapan Anda ?". Dari pertanyaan tersebut, diperoleh jawaban $\mathrm{SB}=26$ orang, $\mathrm{B}=4$ orang dan tidak ada yang memilih $\mathrm{C}$, TB dan STB. Rata-rata yang diperoleh dari jawaban angket adalah $(26 \times 5)+(4 \times 4)=130$ $+16=146 / 30=4,87$. Nilai rata-rata tersebut berinterpretasi sangat tinggi karena berada pada rentang interval $4,20-5,00$.

Item nomer 3 menyatakan "Guru membagi siswa ke dalam beberapa kelompok kecil dalam proses pembelajaran. Bagaimana tanggapan Anda ?”. Dari pertanyaan tersebut, diperoleh jawaban $\mathrm{SB}=9$ orang, $\mathrm{B}=18$ orang, $\mathrm{C}=3$ orang dan tidak ada yang memilih TB dan STB. Rata-rata yang diperoleh dari jawaban angket adalah $(9 \times 5)+$ $(18 \times 4)+(3 \times 3)=45+72+9=126 / 30=4,2$. Nilai rata-rata tersebut berinterpretasi sangat tinggi karena berada pada rentang interval 4,20-5,00.

Item nomer 4 menyatakan "Setelah pembagian kelompok, guru membagi tema kepada beberapa kelompok kecil tersebut. Bagaimana tanggapan Anda ?". Dari pertanyaan tersebut, diperoleh jawaban $\mathrm{SB}=8$ orang, $\mathrm{B}=18$ orang, $\mathrm{C}=4$ orang dan tidak ada yang memilih TB dan STB. Rata-rata yang diperoleh dari jawaban angket adalah $(8 \times 5)+(18 \times 4)+(4 \times 3)=40+72+12=124 / 30=4,13$. Nilai rata-rata tersebut berinterpretasi tinggi karena berada pada rentang interval 3,40-4, 19 .

Item nomer 5 menyatakan "Guru memberikan waktu pada siswa untuk membuat skenario pemodelan. Bagaimana tanggapan Anda ?’. Dari pertanyaan tersebut, diperoleh jawaban $\mathrm{SB}=14$ orang, $\mathrm{B}=14$ orang, $\mathrm{C}=2$ orang dan tidak ada yang memilih TB dan STB. Rata-rata yang diperoleh dari jawaban angket adalah $(14 \times 5)+(14 \times 4)+$ $(2 \times 3)=70+56+6=132 / 30=4,4$. Nilai rata-rata tersebut berinterpretasi sangat tinggi karena berada pada rentang interval 4,20-5,00.

Item nomer 6 menyatakan "Guru memberikan waktu pada siswa untuk berlatih untuk pemodelan. Bagaimana tanggapan Anda ?". Dari pertanyaan tersebut, diperoleh jawaban $\mathrm{SB}=17$ orang, $\mathrm{B}=10$ orang, $\mathrm{C}=3$ orang dan tidak ada yang memilih TB dan STB. Rata-rata yang diperoleh dari jawaban angket adalah $(17 \times 5)+(10 \times 4)+(3 \times 3)=85$ $+40+9=134 / 30=4,47$. Nilai rata-rata tersebut berinterpretasi sangat tinggi karena berada pada rentang interval $4,20-5,00$. 
Item nomer 7 menyatakan "Guru memberikan waktu kepada siswa untuk menampilkan hasil skenario yang dibuat masing-masing kelompok. Bagaimana tanggapan Anda?". Dari pertanyaan tersebut, diperoleh jawaban SB = 12 orang, B = 17 orang, $\mathrm{C}=1$ orang dan tidak ada yang memilih TB dan STB. Rata-rata yang diperoleh dari jawaban angket adalah $(12 \times 5)+(17 \times 4)+(1 \times 3)=60+68+3=131 / 30=4,37$. Nilai rata-rata tersebut berinterpretasi sangat tinggi karena berada pada rentang interval 4,20 $-5,00$.

Item nomer 8 menyatakan "Guru memberikan waktu kepada siswa untuk mengomentari penampilan teman-temannya. Bagaimana tanggapan Anda ?’. Dari pertanyaan tersebut, diperoleh jawaban $\mathrm{SB}=12$ orang, $\mathrm{B}=15$ orang, $\mathrm{C}=3$ orang dan tidak ada yang memilih TB dan STB. Rata-rata yang diperoleh dari jawaban angket adalah $(12 \times 5)+(15 \times 4)+(3 \times 3)=60+60+9=129 / 30=4,3$. Nilai rata-rata tersebut berinterpretasi sangat tinggi karena berada pada rentang interval 4,20-5,00.

Item nomer 9 menyatakan "Setelah semua kelompok maju ke depan, guru memberikan ulasan terhadap pembelajaran. Bagaimana tanggapan Anda ?". Dari pertanyaan tersebut, diperoleh jawaban $\mathrm{SB}=19$ orang, $\mathrm{B}=8$ orang, $\mathrm{C}=3$ orang dan tidak ada yang memilih TB dan STB. Rata-rata yang diperoleh dari jawaban angket adalah $(19 \times 5)+(8 \times 4)+(3 \times 3)=95+32+9=136 / 30=4,53$. Nilai rata-rata tersebut berinterpretasi sangat tinggi karena berada pada rentang interval 4,20-5,00.

Item nomer 10 menyatakan "Guru memberikan penilaian terhadap penampilan masing-masing model kelompok. Bagaimana tanggapan Anda ?". Dari pertanyaan tersebut, diperoleh jawaban $\mathrm{SB}=16$ orang, $\mathrm{B}=11$ orang, $\mathrm{C}=3$ orang dan tidak ada yang memilih TB dan STB. Rata-rata yang diperoleh dari jawaban angket adalah $(16 \times 5)$ $+(11 \times 4)+(3 \times 3)=80+44+9=133 / 30=4,43$. Nilai rata-rata tersebut berinterpretasi sangat tinggi karena berada pada rentang interval 4,20 - 5,00.

Berdasarkan uraian di atas, diperoleh nilai rata-rata 4,27 + 4,87+4,2+4,13+ $4,4+4,47+4,37+4,3+4,53+4,43=43,97 / 10=4,397$. Nilai tersebut termasuk ke dalam kategori interpretasi sangat tinggi karena berada pada rentang interval 4,20 - 5,00. Hal ini menunjukkan tanggapan siswa terhadap penerapan metode pembelajaran Modelling The Way berkategori sangat tinggi.

Uji normalitas ini dimaksudkan untuk mengetahui normal atau tidaknya data megenai tanggapan siswa terhadap penerapan metode pembelajaran Modelling The Way. Berdasarkan hasil perhitungan yang terdapat dalam lampiran, diperoleh harga chi kuadrat hitung $\left(\chi^{2}\right.$ hitung $)=3,22$ dan chi kuadrat tabel $\left(\chi^{2}\right.$ tabel $)=11,34$. Hal ini menunjukkan bahwa chi kuadrat hitung lebih kecil dari chi kuadrat tabel $\left(\chi^{2}\right.$ hitung $=$ $3,22<\chi^{2}$ tabel $\left.=11,34\right)$. Artinya data variabel X (tanggapan siswa terhadap penerapan metode pembelajaran Modelling The Way) adalah berdistribusi normal.

Data yang digunakan untuk mengetahui pelaksanaan ibadah sehari-hari siswa diperoleh dari hasil penyebaran angket kepada siswa kelas 7 SMPN 13 Bandung yang 
berjumlah 30 siswa. Adapun jumlah pertanyaan yang diajukan yaitu sebanyak 15 item yang dikembangkan dari beberapa indikator, yaitu :

a. Shalat jamaah dzuhur,

b. Pembiasaan Baca Tulis Quran (BTQ), dan

c. Pembiasaan shalat dhuha

Angket yang digunakan dalam penelitian ini adalah angket yang dibuat dalam bentuk checklist. Adapun cara mengidentifikasinya adalah berdasarkan kunci jawaban masing-masing berupa alternatif jawaban selalu (S), sering (Se), kadang-kadang (Kd), pernah (P), dan tidak pernah (TP). Pengajuan item angket bersifat positif. Nilai angket tersebut akan ditransformasikan ke dalam bentuk simbol angka kuantitatif. untuk angket yang berorientasi positif, maka sistem penskorannya adalah selalu $(\mathrm{S})$ memiliki skor = 5 , sering $(\mathrm{Se})$ memiliki skor $=4$, kadang-kadang $(\mathrm{Kd})$ memiliki skor $=3$, pernah $(\mathrm{P})$ memiliki skor $=2$, dan tidak pernah $(\mathrm{TP})$ memiliki skor $=1$. Maka dengan mengacu pada teknik perhitungan ini, akan diperoleh skor ideal tertinggi yaitu 15 x $5=75$.

Adapun interpretasi hasil perhitungan menggunakan kriteria sebagai berikut :

$4,20-5,00=$ Sangat tinggi

$3,40-4,19=$ Tinggi

$2,60-3,39=$ Cukup

$1,80-2,59=$ Rendah

$1,00-1,79=$ Sangat rendah

(Arikunto, 2006)

Dengan mempertimbangkan skala penilaian diatas, maka hasil dari komponenkomponen pelaksanaan ibadah sehari-hari siswa dapat dilihat dalam uraian berikut:

Pada indikator ini, peneliti mengajukan lima item pertanyaan, yaitu pertanyaan nomer 1 sampai nomer 5. Item nomer 1 menyatakan "Saya melaksanakan shalat 5 waktu dengan rajin". Dari pernyataan tersebut, diperoleh jawaban $\mathrm{S}=15$ orang, $\mathrm{Se}=9$ orang, $\mathrm{Kd}=6$ orang dan tidak ada yang memilih jawaban P dan TP. Rata-rata yang diperoleh dari jawaban angket adalah $(15 \times 5)+(9 \times 4)+(6 \times 3)=75+36+18=129 / 30=4,3$. Nilai rata-rata tersebut berinterpretasi sangat tinggi karena berada pada rentang interval 4,20 $-5,00$.

Item nomer 2 menyatakan "Saya melaksanakan shalat Dzuhur berjamaah". Dari pernyataan tersebut, diperoleh jawaban $\mathrm{S}=8$ orang, $\mathrm{Se}=5$ orang, $\mathrm{Kd}=15$ orang, $\mathrm{P}=2$ orang, dan tidak ada yang memilih jawaban TP. Rata-rata yang diperoleh dari jawaban angket adalah $(8 \times 5)+(5 \times 4)+(15 \times 3)+(2 \times 2)=40+20+45+4=109 / 30=3,63$. Nilai rata-rata tersebut berinterpretasi tinggi karena berada pada rentang interval 3,40-4,19.

Item nomer 3 menyatakan "Saya melaksanakan shalat Dzuhur di masjid". Dari pernyataan tersebut, diperoleh jawaban $\mathrm{S}=8$ orang, $\mathrm{Se}=5$ orang, $\mathrm{Kd}=14$ orang, $\mathrm{P}=2$ orang, dan $\mathrm{TP}=1$ orang. Rata-rata yang diperoleh dari jawaban angket adalah $(8 \times 5)+$ $(5 \times 4)+(14 \times 3)+(2 \times 2)+(1 \times 1)=40+20+42+4+1=107 / 30=3,57$. Nilai rata-rata tersebut berinterpretasi tinggi karena berada pada rentang interval 3,40 - 4,19. 
Item nomer 4 menyatakan "Saya melaksanakan shalat Dzuhur tepat waktu". Dari pernyataan tersebut, diperoleh jawaban $\mathrm{S}=5$ orang, $\mathrm{Se}=8$ orang, $\mathrm{Kd}=15$ orang, $\mathrm{P}=2$ orang, dan tidak ada yang memilih jawaban TP. Rata-rata yang diperoleh dari jawaban angket adalah $(5 \times 5)+(8 \times 4)+(15 \times 3)+(2 \times 2)=25+32+45+4=106 / 30=3,53$. Nilai rata-rata tersebut berinterpretasi tinggi karena berada pada rentang interval 3,40-4,19.

Item nomer 5 menyatakan "Saya melaksanakan shalat Dzuhur tanpa paksaan". Dari pernyataan tersebut, diperoleh jawaban $\mathrm{S}=12$ orang, $\mathrm{Se}=8$ orang, $\mathrm{Kd}=7$ orang, $\mathrm{P}=3$ orang dan tidak ada yang memilih pilihan jawaban TP. Rata-rata yang diperoleh dari jawaban angket adalah $(12 \times 5)+(8 \times 4)+(7 \times 3)+(3 \times 2)=60+32+21+6=119 / 30$ $=3,97$. Nilai rata-rata tersebut berinterpretasi tinggi karena berada pada rentang interval $3,40-4,19$.

Dari kelima pertanyaan yang diajukan pada indikator shalat jamaah dzuhur tersebut, diperoleh nilai rata-rata 4,3 $+3,63+3,57+3,53+3,97=19 / 5=3,8$. Nilai tersebut termasuk ke dalam kategori interpretasi tinggi karena berada pada rentang interval 3,40-4,19. Hal ini menunjukkan bahwa pelaksanaan ibadah sehari-hari siswa yang berupa shalat jamaah dzuhur berkategori tinggi.

Pada indikator ini, peneliti mengajukan lima item pertanyaan, yaitu pertanyaan nomer 6 sampai nomer 10. Item nomer 6 menyatakan "Saya mengikuti pembiasaan baca tulis Quran (BTQ)". Dari pernyataan tersebut, diperoleh jawaban $\mathrm{S}=5$ orang, $\mathrm{Se}=8$ orang, $\mathrm{Kd}=16$ orang, $\mathrm{P}=1$ orang dan tidak ada yang memilih pilihan jawaban TP. Ratarata yang diperoleh dari jawaban angket adalah $(5 \times 5)+(8 \times 4)+(16 \times 3)+(1 \times 2)=25+$ $32+48+2=107 / 30=3,57$. Nilai rata-rata tersebut berinterpretasi tinggi karena berada pada rentang interval 3,40-4,19.

Item nomer 7 menyatakan "Saya mengikuti pembiasaan baca tulis Quran (BTQ) karena ingin belajar". Dari pernyataan tersebut, diperoleh jawaban $\mathrm{S}=9$ orang, $\mathrm{Se}=13$ orang, $\mathrm{Kd}=8$ orang dan tidak ada yang memilih pilihan jawaban P dan TP. Rata-rata yang diperoleh dari jawaban angket adalah $(9 \times 5)+(13 \times 4)+(8 \times 3)=45+52+24=$ $121 / 30=4,03$. Nilai rata-rata tersebut berinterpretasi tinggi karena berada pada rentang interval 3,40-4,19.

Item nomer 8 menyatakan "Saya mengikuti pembiasaan baca tulis Quran (BTQ) tanpa paksaan". Dari pernyataan tersebut, diperoleh jawaban $\mathrm{S}=6$ orang, $\mathrm{Se}=10$ orang, $\mathrm{Kd}=13$ orang, $\mathrm{P}=1$ orang, dan tidak ada yang memilih pilihan jawaban TP. Rata-rata yang diperoleh dari jawaban angket adalah $(6 \times 5)+(10 \times 4)+(13 \times 3)+(1 \times 2)=30+40+$ $39+2=111 / 30=3,7$. Nilai rata-rata tersebut berinterpretasi tinggi karena berada pada rentang interval 3,40-4,19.

Item nomer 9 menyatakan "Saya mengikuti pembiasaan baca tulis Quran (BTQ) bukan karena teman". Dari pernyataan tersebut, diperoleh jawaban $S=12$ orang, $\mathrm{Se}=4$ orang, $\mathrm{Kd}=11$ orang, $\mathrm{P}=2$ orang, dan $\mathrm{TP}=1$ orang. Rata-rata yang diperoleh dari jawaban angket adalah $(12 \times 5)+(4 \times 4)+(11 \times 3)+(2 \times 2)+(1 \times 1)=60+16+33+4+1$ 
$=114 / 30=3,8$. Nilai rata-rata tersebut berinterpretasi tinggi karena berada pada rentang interval 3,40-4,19.

Item nomer 10 menyatakan "Saya datang lebih awal untuk mengikuti pembiasaan baca tulis Quran (BTQ)". Dari pernyataan tersebut, diperoleh jawaban $\mathrm{S}=$ 3 orang, $\mathrm{Se}=3$ orang, $\mathrm{Kd}=18$ orang, $\mathrm{P}=4$ orang, dan $\mathrm{TP}=2$ orang. Rata-rata yang diperoleh dari jawaban angket adalah $(3 \times 5)+(3 \times 4)+(18 \times 3)+(4 \times 2)+(2 \times 1)=15+12$ $+54+8+2=91 / 30=3,03$. Nilai rata-rata tersebut berinterpretasi cukup karena berada pada rentang interval 2,60-3,39.

Dari kelima pertanyaan yang diajukan pada indikator pembiasaan Baca Tulis Quran (BTQ) tersebut, diperoleh nilai rata-rata 3,57 + 4,03 + 3,7 + 3,8 + 3,03 $=18,13 / 5$ $=3,62$. Nilai tersebut termasuk berinterpretasi tinggi karena berada pada rentang interval 3,40 - 4,19. Hal ini menunjukkan bahwa pelaksanaan ibadah sehari-hari siswa yang berupa pembiasaan Baca Tulis Quran (BTQ), berkategori tinggi.

Pada indikator ini, peneliti mengajukan lima item pertanyaan, yaitu pertanyaan nomer 11 sampai nomer 15. Item nomer 11 menyatakan "Saya mengikuti pembiasaan shalat Dhuha dengan rajin". Dari pernyataan tersebut, diperoleh jawaban $\mathrm{S}=12$ orang, $\mathrm{Se}=9$ orang, $\mathrm{Kd}=8$ orang, $\mathrm{P}=1$ orang, dan tidak ada yang memilih pilihan jawaban TP. Rata-rata yang diperoleh dari jawaban angket adalah $(12 \times 5)+(9 \times 4)+(8 \times 3)+(1 \times 2)$ $=60+36+24+2=122 / 30=4,07$. Nilai tersebut termasuk berinterpretasi tinggi karena berada pada rentang interval 3,40-4,19.

Item nomer 12 menyatakan "Saya datang lebih awal untuk mengikuti pembiasaan shalat Dhuha". Dari pernyataan tersebut, diperoleh jawaban $\mathrm{S}=12$ orang, $\mathrm{Se}=9$ orang, $\mathrm{Kd}=7$ orang, $\mathrm{P}=2$ orang, dan tidak ada yang memilih pilihan jawaban TP. Rata-rata yang diperoleh dari jawaban angket adalah $(12 \times 5)+(9 \times 4)+(7 \times 3)+(2 \times 2)$ $=60+36+21+4=121 / 30=4,03$. Nilai tersebut termasuk berinterpretasi tinggi karena berada pada rentang interval $3,40-4,19$.

Item nomer 13 menyatakan "Saya mengikuti pembiasaan shalat Dhuha tanpa paksaan". Dari pernyataan tersebut, diperoleh jawaban $\mathrm{S}=9$ orang, $\mathrm{Se}=10$ orang, $\mathrm{Kd}$ $=8$ orang, $\mathrm{P}=3$ orang dan tidak ada yang memilih pilihan jawaban TP. Rata-rata yang diperoleh dari jawaban angket adalah $(9 \times 5)+(10 \times 4)+(8 \times 3)+(3 \times 2)=45+40+24+$ $6=115 / 30=3,83$. Nilai rata-rata tersebut berinterpretasi tinggi karena berada pada rentang interval 3,40-4,19.

Item nomer 14 menyatakan "Saya tidak terlambat ketika jadwal pembiasaan shalat Dhuha". Dari pernyataan tersebut, diperoleh jawaban $S=9$ orang, $\mathrm{Se}=10$ orang, $\mathrm{Kd}=10$ orang, $\mathrm{TP}=1$ orang, dan tidak ada yang memilih pilihan jawaban $\mathrm{P}$. Rata-rata yang diperoleh dari jawaban angket adalah $(9 \times 5)+(10 \times 4)+(10 \times 3)+(1 \times 1)=45+40+$ $30+1=116 / 30=3,87$. Nilai rata-rata tersebut berinterpretasi tinggi karena berada pada rentang interval 3,40-4,19.

Item nomer 15 menyatakan "Saya mengikuti pembiasaan shalat Dhuha dengan khidmat". Dari pernyataan tersebut, diperoleh jawaban $\mathrm{S}=13$ orang, $\mathrm{Se}=13$ orang, $\mathrm{Kd}$ 
= 4 orang, dan tidak ada yang memilih pilihan jawaban P dan TP. Rata-rata yang diperoleh dari jawaban angket adalah $(13 \times 5)+(13 \times 4)+(4 \times 3)=65+52+12=129 / 30$ $=4,3$. Nilai rata-rata tersebut berinterpetasi sangat tinggi karena berada pada rentang interval 4,20-5,00.

Dari kelima pertanyaan yang diajukan pada indikator pembiasaan shalat dhuha tersebut, diperoleh nilai rata-rata 4,07 +4,03+3,83+3,87+4,3=20,1/5=4,02. Nilai tersebut termasuk ke dalam kategori interpretasi tinggi karena berada pada rentang interval 3,40 - 4,19. Hal ini menunjukkan bahwa pelaksanaan ibadah sehari-hari siswa yang berupa pembiasaan shalat dhuha berkategori tinggi.

Berdasarkan uraian perindikator di atas, rata-rata yang diperoleh adalah 3,8+ $3,62+4,02=11,44 / 3=3,81$. Nilai atau angka tersebut termasuk ke dalam kategori interpretasi tinggi, karena berada pada interval 3,40-4, 19. Dengan demikian, dapat dikatakan bahwa pelaksanaan ibadah sehari-hari siswa berinterpretasi tinggi.

Uji normalitas ini dimaksudkan untuk mengetahui normal atau tidaknya data megenai pelaksanaan ibadah sehari-hari siswa. Berdasarkan hasil perhitungan yang terdapat dalam lampiran, diperoleh harga chi kuadrat hitung $\left(\chi^{2}\right.$ hitung $)=7,99$ dan chi kuadrat tabel $\left(\chi^{2}\right.$ tabel $)=11,34$. Hal ini menunjukkan bahwa chi kuadrat hitung lebih kecil dari chi kuadrat tabel $\left(\chi^{2}\right.$ hitung $=7,99<\chi^{2}$ tabel $\left.=11,34\right)$. Artinya data variabel $\mathrm{Y}$ (pelaksanaan ibadah sehari-hari siswa) adalah berdistribusi normal.

Untuk mengetahui dan membuktikan ada tidaknya pengaruh tanggapan siswa terhadap penerapan metode pembelajaran Modelling The Way terhadap pelaksanaan ibadah sehari-hari siswa, maka penulis melakukan uji linieritas regresi dan uji korelasi yang akan diuraikan sebagai berikut:

\section{Menentukan Linieritas Regresi}

Analisis ini dimaksudkan untuk mengetahui bentuk pengaruh tanggapan siswa terhadap penerapan metode pembelajaran Modelling The Way terhadap pelaksanaan ibadah sehari-hari siswa. Dari hasil perhitungan terhadap persamaan regresi $\mathrm{Y}=\mathrm{a}+\mathrm{b}$ (X) diketahui hasil $\mathrm{a}=-6,38$ dan hasil $\mathrm{b}=0,01$. Dengan demikian hubungan antara variabel $\mathrm{X}$ dan variabel $\mathrm{Y}$ dapat dirumuskan dengan bentuk persamaan regresi $\mathrm{Y}=-6,38$ $+0,01(\mathrm{X})$.

\section{Hasil Uji Linieritas Regresi}

Dari hasil perhitungan linieritas regresi, diperoleh data $\mathrm{F}_{\text {hitung }}=1,31$ dan $\mathrm{F}_{\text {tabel }}=$ 3,52. Maka dari hasil tersebut terbukti bahwa $F_{\text {hitung }}<$ dari pada $F_{\text {tabel }}(1,31<3,52)$. Dengan demikian dapat disimpulkan bahwa antara variabel X, yaitu tanggapan siswa terhadap penerapan metode pembelajaran Modelling The Way dan pelaksanaan ibadah sehari-hari siswa sebagai variabel Y, berregresi linier. Atau dengan kata lain bahwa regresi $\mathrm{Y}$ atas $\mathrm{X}$ linier.

\section{Koefisien Korelasi}

Analisis ini dilakukan untuk mengukur jumlah derajat pengaruh tanggapan siswa terhadap penerapan metode pembelajaran Modelling The Way (variabel X) terhadap 
pelaksanaan ibadah sehari-hari siswa (variabel Y). Dalam koefisien korelasi ini menggunakan rumus rank korelasi dari Spearman.

Berdasarkan hasil analisis data ternyata diperoleh hasil koefisien korelasi sebesar 0,67 yang berada pada interval korelasi antara 0,60 - 0,69 dengan kualifikasi tinggi. Dengan demikian tingkat pengaruh tanggapan siswa terhadap penerapan metode pembelajaran Modelling The Way terhadap pelaksanaan ibadah sehari-hari siswa tinggi.

\section{Pengujian Hipotesis}

Berdasarkan perhitungan hasil uji hipotesis diketahui bahwa t hitung sebesar 4,78 sementara $t$ tabel pada taraf signifikansi $1 \%$ dan derajat kebebasan $d b=28$ diperoleh angka sebesar 2,763. Dari hasil tersebut terbukti t hitung lebih besar dari pada t tabel $(4,78>2,763)$. Kenyataan seperti ini menunjukkan bahwa hipotesis nol (Ho) ditolak sedangkan hipotesis alternatif (Ha) diterima. Dengan kata lain Penerapan metode pembelajaran Modelling The Way pada mata pelajaran PAI sub bab Fiqih berpengaruh terhadap pelaksanaan ibadah sehari-hari siswa di SMP Negeri 17 Bandung.

\section{Pengaruh Variabel $X$ terhadap Variabel $Y$}

Berdasarkan perhitungan tentang besar kecilnya pengaruh variabel $\mathrm{X}$ terhadap variabel Y, tanggapan siswa pada penerapan metode pembelajaran Modelling The Way pada mata pelajaran PAI sub bab Fiqih berpengaruh terhadap pelaksanaan ibadah seharihari siswa di SMP Negeri 17 Bandung, besar pengaruhnya tersebut adalah 26\%. Angka tersebut menyatakan bahwa masih ada faktor lain sebesar $74 \%$ yang mempengaruhi pelaksanaan ibadah sehari-hari siswa.

Hasil penelitian ini memberikan gambaran bahwa tanggapan siswa pada penerapan metode pembelajaran Modelling The Way pada mata pelajaran PAI sub bab Fiqih berpengaruh terhadap pelaksanaan ibadah sehari-hari siswa di SMP Negeri 17 Bandung. Hal ini sejalan dengan kajian pustaka yang telah dilakukan sebelumnya bahwa metode Modelling The Way ini dapat mengasah siswa lebih aktif dalam belajar terutama dalam aspek psikomotor. Pelaksanaan ibadah sehari-hari yang diprogramkan oleh pihak SMP Negeri 17 Bandung diantaranya adalah pelaksanaan shalat dzuhur berjamaah, pelaksanaan pembiasaan Baca Tulis Quran (BTQ) dan pembiasaan shalat dhuha setiap hari Jumat.

Terlepas dari metode yang baik, tentunya ada beberapa hal yang mempengaruhi kualitas pelaksanaan ibadah sehari-hari mereka, baik dari internal siswa maupun eksternalnya. Hal ini lah yang mesti kita gali terus , sehingga ketercapaian tujuan program yang menjadikan siswa beriman dan beramal sholeh itu tinggi.

\section{SIMPULAN}

Berdasarkan analisis data dari hasil penelitian dan pembahasan mengenai tanggapan siswa terhadap penerapan metode pembelajaran Modelling The Way pengaruhnya terhadap pelaksanaan ibadah sehari-hari siswa, dapat disimpulkan sebagai berikut : 
1. Tanggapan siswa terhadap penerapan metode pembelajaran Modelling The Way berdasarkan hasil perhitungan statistik diperoleh nilai rata-rata akhir sebesar 4,397. Angka tersebut berada pada interval 4,20 - 5,00. Hal ini menunjukkan bahwa tanggapan siswa terhadap penerapan metode pembelajaran Modelling The Way adalah berinterpretasi sangat tinggi.

2. Pelaksanaan ibadah sehari-hari siswa berdasarkan hasil perhitungan statistik diperoleh nilai rata-rata akhir sebesar 3,81. Angka tersebut berada pada interval $3,40-4,19$. Hal ini menunjukkan bahwa pelaksanaan ibadah sehari-hari siswa adalah berinterpretasi tinggi.

3. Tanggapan siswa terhadap penerapan metode pembelajaran Modelling The Way pengaruhnya terhadap pelaksanaan ibadah sehari-hari siswa memiliki koefisien korelasi sebesar 0,67 yang berada pada interval 0,60-0,69. Hal ini menunjukkan bahwa tanggapan siswa terhadap penerapan metode pembelajaran Modelling The Way terhadap pelaksanaan ibadah sehari-hari siswa memiliki pengaruh yang tinggi. Hasil pengujian hipotesis dengan taraf signifikansi $1 \%$ menunjukkan $\mathrm{t}_{\text {hitung }}(4,78)>\mathrm{t}_{\text {tabel }}(2,763)$. Dengan demikian, dapat dinyatakan bahwa hipotesis diterima, yang artinya tanggapan siswa terhadap penerapan metode pembelajaran Modelling The Way berpengaruh terhadap pelaksanaan ibadah sehari-hari siswa. Kadar pengaruh tanggapan siswa terhadap penerapan metode pembelajaran Modelling The Way terhadap pelaksanaan ibadah sehari-hari siswa adalah sebesar 26\%. Artinya, masih ada sebesar $74 \%$ faktor lain yang memengaruhi pelaksanaan ibadah sehari-hari siswa, baik faktor internal maupun faktor eksternal.

\section{DAFTAR PUSTAKA}

Ahmadi, Abu. (2009). Psikologi Umum. Jakarta: Rineka Cipta.

Anas, Sudijono. (2005). Statistik Pendidikan. Bandung: PT. Raja Grafindo.

Arief, Armai. (2002). Pengantar Ilmu dan Metodologi Pendidikan Islam. Tanggerang:

Ciputat Pers.

Arikunto, Suharsimi. (2006). Dasar-dasar Evaluasi Pendidikan. Jakarta: Rineka Cipta. Azzet, Akhmad Muhaimin. (2010). 7 Cara Agar Rezeki Semakin Bertambah dan Barakah. Yogyakarta: Diva Press.

Badrudin, dkk. (2014). Bahasa Indonesia. Bandung: CV. Insan Mandiri.

Baharuddin. (2007). Psikologi Pendidikan. Yogyakarta: Ar Ruzz Media.

Creswell, John. (2015). Riset Pendidikan. Yogyakarta: Pustaka Pelajar.

Dalyono, Muhammad. (2012). Psikologi Pendidikan. Jakarta: Rineka Cipta.

Dedih, Ujang. (2012). Fiqih Ibadah. Bandung: CV. Insan Mandiri.

Djaali. (2013). Psikologi Pendidikan. Jakarta: Bumi Aksari.

Djamarah. (2011). Psikologi Belajar. Jakarta: Rineka Cipta.

Ghazali, Imam. (2008). Bertambah Kaya Lewat Shalat Dhuha. Mitra Press. 
Hayati, Tuti. (2014). Pengantar Statistika Pendidikan. Bandung: CV. Insan Mandiri.

Jamaludin, dkk. (2015). Belajar Pembelajaran Perspektif Islam. Bandung: PT. Remaja Rosdakarya

Muhidin, Sambas Ali. (2009). Analisis Korelasi Regresi dan Jalur dalam Penelitian. Bandung: Pustaka Setia.

Pieter, Heri Zan. (2010). Pengantar Psikologi untuk Kebidanan. Jakarta: Kencana Prenada Media Group.

Rasjid, Sulaiman. (2010). Fiqh Islam. Bandung: Sinar Baru Algesindo.

Rifai, Moh. (2010). Risalah Tuntunan Shalat Lengkap. Semarang: PT. Karya Toha Putra.

Salahudin, Anas. (2016). Bimbingan dan Konseling. Bandung: CV. Pustaka Setia.

Shidiq, Sapiudin. (2017). Ushul Fiqh. Jakarta: Kencana Prenada Media Group.

Silberman, M. L. (2007). Active Learning 101 Metode Pembelajaran Aktif. Yogyakarta: Pustaka Insan Madani.

Soemanto, Wasty. (2012). Psikologi Pendidikan. Jakarta: Rineka Cipta.

Subana. (2000). Statistik Pendidikan. Bandung: Pustaka setia.

Sudjana, Nana. (2001). Penilaian Hasil Proses Belajar Mengajar. Bandung: PT. Remaja Rosdakarya.

Sujanto, Agus. (2012). Psikologi Umum. Jakarta: Bumi Aksara.

Suryabrata, Sumadi. (2011). Psikologi Pendidikan. Jakarta: Raja Grafindo Persada.

Syafei, Rachmat. (2001). Fiqih Muamalah. Bandung: Pustaka Setia.

Syah, Muhibbin. (2014). Psikologi Pendidikan dengan Pendekatan Baru. Bandung: PT. Remaja Rosdakarya.

Syarifudin, Amir. (2014). Garis-garis Besar Ushul Fiqh. Jakarta: Kencana Prenada Media Group.

Zaini, Hisyam. (2008). Strategi Pembelajaran Aktif. Yogyakarta: Pustaka Insan

Madani. 